\title{
Pengaruh Media Slide Pada Mata Pelajaran Sistem Karburator untuk Meningkatkan Hasil Belajar Siswa Kelas 11 TBSM SMK N 8 Purworejo
}

\author{
Gani Aulia Agasta, Widiyatmoko, Mike Elly Anitasari \\ Progan Studi Pendidikan Teknik Otomotif, Universitas Muhamadiyah Purworejo \\ E-mail: agastagani@gmail.com
}

\section{ABSTRAK}

Penelitian ini bertujuan untuk mengetahui penerapan metode pembeajaran dengan media slide yang mempengaruhi hasil belajar siswa kelas XI TBSM SMK N 8 Purworejo. Jenis penelitian ini adalah penelitian tindakan kelas dengan jumlah responden sebanyak 32 siswa kelas XI TBSM SMK N 8 Purworejo. Instrumen yang digunakan dalam penelitian ini adalah lembar penilaian yang berupa soal. Analisis data menggunakan tabel presentase. Jenis penelitian ini adalah penelitian tindakan kelas dengan jumlah responden 32 siswa kelas XI TBSM SMK N 8 Purworejo. Instrumen yang digunakan dalam penelitian ini adalah lembar penilaian yang berupa soal. Analisis data yang digunakan taraf kesukaran dan daya beda. Dari hasil penelitian terdapat perbedaan Hasil belajar siswa kelas XI TBSM SMK N 8 Purworejo Dari tabel diatas siklus I memperoleh nilai rata-rata sebesar 53,17 dan siklus II mendapatkan nilai rata-rata sebesar 68,5 terdapat peningkatan yang cukup siginifikan yaitu sebesar $15,33 \%$.

\section{Kata Kunci: Media Slide, Materi Karburator, Hasil Belajar}

\section{PENDAHULUAN}

Pendidikan merupakan salah satu kebutuhan penting yang harus dipenuhi oleh manusia dalam kehidupan bermasyarakat dan bernegara. Pendidikan dapat menjadikan manusia yang berkualitas, bermoral, dan berketuhanan Yang Maha Esa. Hal tersebut merupakan prioritas utama sebagai upaya mengangkat bangsa Indonesia dari keterbelakangan dan ketinggalan dari bangsa lain.

Tujuan dari sekolah kejuruan salah satunya adalah mempersiapkan mempersiapkan peserta didik yang memiliki daya saing tinggi guna bersaing dalam 
dunia industry dengan keahlian yang mereka miliki, tapi tidak menuntut kemungkinan untuk melanjutkan ke perguruan tinggi ataupun berwirausaha. Keberhasilan suatu tujuan pendidikan dalam sekolah kejuruan tidak hanya berpengaruh pada guru, namun ada beberapa faktor salah satunya adalah motivasi belajar siswa dan sarana prasarana yang mendukung dalam proses pembelajaran

Berdasarkan pengamatan dan observasi tersebut, pada Mata Pelajaran TBSM dengan Kompetensi Sistem Karburator kelas XI TBSM SMK N 8 Purworejo, diketahui terdapapat beberapa permasalahan dalam proses belajar mengajar yaitu: kurangnya minat belajar pada siswa. Diketahui dalam pembelajaran, siswa kurang memperhatikan pembelajaran, kurangnya interaksi antara siswa dengan guru dalam hal tanya jawab materi pelajaran yang belum dimengerti, siswa cenderung diam ketika mereka merasa tidak mengerti dengan materi pelajaran yang diajarkan, kurangnya kerjasama antar siswa tercermin ketika proses diskusi berlangsung, rendahnya hasil belajar yang diketahui berdasarkan pengamatan dan observasi, pada Mata Pelajaran TBSM dengan Kompetensi Sistem Karburator kelas XI TBSM di SMK N 8 Purworejo memperoleh hasil belajar yang kurang baik pada materi sistem karburator.

Atas dasar inilah peneliti membuat judul "Penerapan Model Pembelajaran dengan menggunakan media slide untuk meningkatkan Hasil Belajar Siswa Kelas XI TBSM Pada Kompetensi Sistem Karburator di SMK N 8 Purworejo

\section{METODE PENELITIAN}

Penelitian ini merupakan jenis penelitian tindakan atau action reserch, penelitian tidak cocok untuk parapraktisi yang bergelut degan dunia nyata. Kita mungkin heran istilah peneliian yang biasanya berkenaan dengan teori sekarang dijadihkan dengan istilah tindakan ( kemmis \& Mc Tegart, 1998) ( Aqib \& Amrullah,2019). Menurut Arikunto (2011: 128) secara harfiah, 
penelitian tindakan kelas berasal dari bahasa inggris yaitu: Classroom Action Reasarch yang berarti (penelitian dengan tindakan) yang dilakukan.

Penelitian ini dlakukan di SMK N 8 Purworejo. Penelitian selama tiga bulan, dimulai bulan April sampai dengan Juni 2020. Subjek penelitian ini adalah siswa kelas XI TBSM SMK N 8 Purworejo yang berjumlah 30 siswa.

Teknik pengumpulan data yang digunakan yaitu observasi dan dokumetasi. Instrumen yang digunakan dalam penelitian ini adalah lembar soal.

\section{HASIL PENELITIAN DAN PEMBAHASAN}

Pada penelitian tindakan kelas ini, pembelajaran akan dilaksanakan 2 siklus pada setiap siklus dilaksanakan 1 kali pertemuan dengan alokasi waktu 3x 25 Menit denggan menggunakan Google Form sebagai media ajar. Teknik pengumpulan data yang digunakan adalah tes tertulis yang telah peneliti buat melalui Google Form

Lembar soal yang diguakan untuk pengukuran peningkatan hasil belajar terdiri dari 20 butir soal. Hasil dari lembar soal hasil belajar dilakukan pada siklus 1 dan siklus 2 diperoleh rata-rata pada setiap siklusnya, dapat dilihat pada tabel berikut

Tabel.1

Hasil Belajar Siklus I dan Siklus II

\begin{tabular}{|l|l|}
\hline \multicolumn{2}{|l|}{ Hasil Belajar } \\
\hline Siklus I & Siklus II \\
\hline 53,17 & 68,5 \\
\hline
\end{tabular}

Tabel 1 diatas menunjukan bahwa rata-rata siklus 1 53,17 dan siklus II 68,5 sehingga dapat disimpulkan adanya peningkatan sebanyak 15,33\%. Peningkatan hasil belajar siswa juga disajikan pada gambar berikut : 


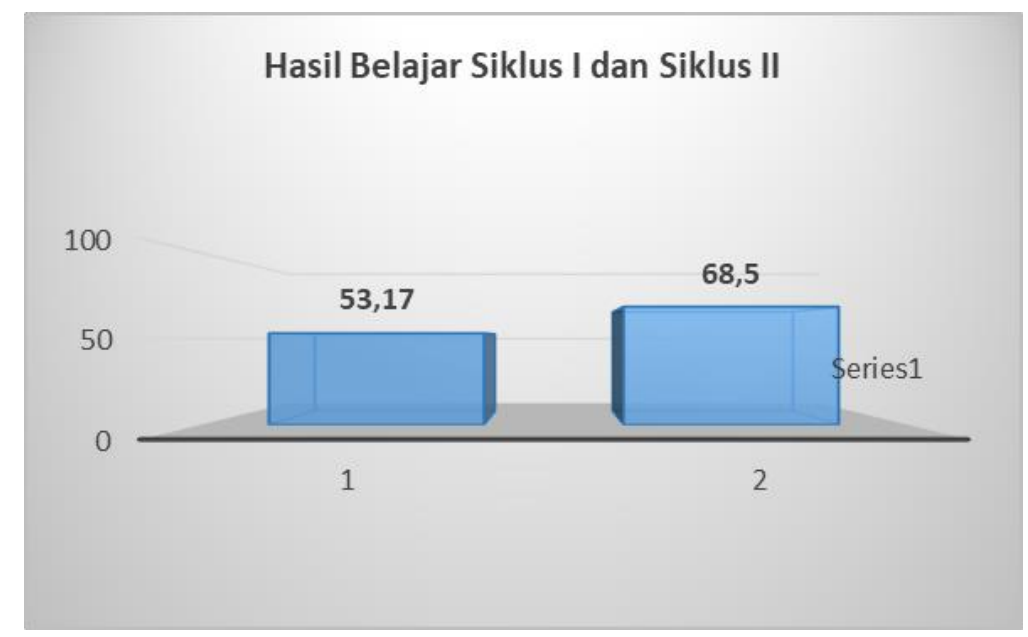

Gambar.1

Hasil Belajar Siklus I dan Siklus II

Hasil dari tabel 1 dan gambar 1 terlihat bahwa pelaksanaan tindakan kelas dari tiap siklus mengalami peningkatan. Peningkaan ini menjadi tolak ukur bahwa hasil belajar siswa dapat ditingkatkan dengan media slide.

\section{KESIMPULAN}

Berdasarkan hasil penelitian dan pembahasan maka dapat ditarik kesimpulan sebagai berikut :

1. Dari hasil pembelajaran dikelas menggunakan media berbasis slide sebagai media dalam menyampaikan materi sistem karburator terdapat beberapa keuntungan atau kelebihan diantara lain :

a. Bertambahnya minat belajar peserta didik pada saat pembelajaraan kususnya pada materi sistem karburator dengan menggunakan media berbasis slide di karenakan dengan media tersebut peserta didik dapat 
melihat dengan jelas materi yang ditampilkan dan dapat juga melihat tayangan gambar atau video yang sesuai dengan nyatanya.

b. Siswa lebih memperhatikan pada sat proses pembelajaran dikarenakan terdapat media yang digunakan menarik.

c. Meningkatnya pemahaman siswa terhadap materi sistem karburator yang di sampaikan dengan bukti peningkatan hasil belajar yang diperoleh.

2. Dari hasil evaluasi hasil belajar siswa pada siklus pertama menunjukkan belum optimal dengan Nilai rata-rata 53,17 nilai tertinggi 85 dan nilai terendah 20 dengan kriteria sebanyak 13 peserta didik mendapatkan nilai dalam kategori kurang sekali, 9 peserta didik mendapatkan nilai dalam kategori kurang 3 peserta didik mendapatkan nilai dalam kategori cukup dan 5 peserta didik mendapatkan nilai dalam kategori baik. Dari data diatas maka peserta yang di nyatakan melebihi KKM adalah 4 siswa.

3. Dari hasil evaluasi hasil belajar siswa pada siklus II menunjukkan sudah optimal dengan Nilai rata-rata 68,5 nilai tertinggi 90 dan nilai terendah 30 dengan kriteria sebanyak 5 peserta didik mendapatkan nilai dalam kategori kurang sekali, 6 peserta didik mendapatkan nilai dalam kategori kurang 1 peserta didik mendapatkan nilai dalam kategori cukup dan 18 peserta didik mendapatkan nilai dalam kategori baik. Dari data diatas maka peserta yang di nyatakan melebihi KKM adalah 18 siswa.

4. Dari tabel diatas siklus I memperoleh nilai rata-rata sebesar 53,17 dan siklus II mendapatkan nilai rata-rata sebesar 68,5 terdapat peningkatan yang cukup siginifikan yaitu sebesar 15,33. Dari peningkatan hasil belajar tersebut dapat disimpulan bahwa media berbasis slide dapat digunakan dengan baik dalam meningkatkan hasil belajar siswa khususnya dalam materi sistem karburator. 


\section{DAFTAR PUSTAKA}

Aqib,Z.,\&Amrullah,A(2019). PTK,PTS,PTBK-Penelitian Tindakan Kelas, Penelitian Tindakan Sekolah, Penelitian Tindakan BimbinganKonseling-Teori dan Aplikasi. (FI. Sigit Suyantoro,Ed). Yogyakarta:ANDI Yogyakarta.

Arikunto, Suharsimi. 2011. Prosedur Penelitian: Suatu Pendekatan Praktik Edisi Revisi VII. Jakarta: PT. Rineka Cipta

Kurnia, F., \& Suyitno, S. (2018). UPAYA PENINGKATAN KEAKTIFAN DAN HASIL BELAJAR SISWA DENGAN PENERAPAN MEDIA PEMBELAJARAN POMPA BAHAN BAKAR TIPE DISTRIBUTOR DI SMK N 4 PURWOREJO. Auto Tech: Jurnal Pendidikan Teknik Otomotif Universitas Muhammadiyah Purworejo, 12(01). http://ejournal.umpwr.ac.id/index.php/autotext/article/view/4870/4474

Rohmanato, R., \& Suyitno, S. (2018). PENGEMBANGAN MEDIA PEMBELAJARAN SISTEM KEMUDI TIPE RACK AND PINION UNTUK MENINGKATKAN PRESTASI BELAJAR SISWA PADA MATA PELAJARAN CHASSIS KELAS XI TKR SMKN 6 PURWOREJO TAHUN AJARAN 2016/2017. Auto Tech: Jurnal Pendidikan Teknik Otomotif Universitas Muhammadiyah Purworejo, 12(01).

Prasmoro, W. J., \& Suparmin, S. (2015). KORELASI PRESTASI PRAKTIK INDUSTRI DAN WAWASAN WIRAUSAHA DENGAN MINAT BERWIRAUSAHA SISWA KELAS XII PROGRAM KEAHLIAN TEKNIK KENDARAAN RINGAN SMK YPT PURWOREJO TAHUN PELAJARAN 2014/2015. TAMAN VOKASI, 3(1). http://ejournal.umpwr.ac.id/index.php/autotext/article/view/4877/4481

Hidayat, C. T., \& Suyitno, S. (2018). PENGEMBANGAN MEDIA PEMBELAJARAN SISTEM POMPA BAHAN BAKAR MOTOR DIESEL TIPE DISTRIBUTOR TERHADAP HASIL BELAJAR SISWA KELAS XII TKR SMK N 1 GOMBONG TAHUN AJARAN 2016/2017. Auto Tech: Jurnal Pendidikan Teknik Otomotif Universitas Muhammadiyah Purworejo, 11(02).

http://ejournal.umpwr.ac.id/index.php/autotext/article/view/4318/4020

Kuntoro, R., \& Suyitno, S. (2018). PENGEMBANGAN MEDIA PEMBELAJARAN SISTEM KEMUDI UNTUK MENINGKATKAN HASIL BELAJAR SISWA XII TKR SMK N 1 PURING TAHUN AJARAN 2016/2017. Auto Tech: Jurnal Pendidikan Teknik Otomotif Universitas Muhammadiyah

Purworejo, 11(02). http://ejournal.umpwr.ac.id/index.php/autotext/article/view/4321/4023

Suyitno, S., Pardjono, P., \& Sofyan, H. (2017). Work Based Learning Terintegrasi Konsep, strategi dan implementasi dalam pendidikan kejuruan.

Suyitno, S. (2018). Penelitian Tindakan Kelas, Eksperimen dan R \& D. Alfabeta. Bandung. 